International Journal of Engineering \& Technology, $7(4.38)(2018) 814-817$
International Journal of Engineering \& Technology
SPC
Website: $w$ ww.sciencepubco.com/index.php/IJET
Research paper

\title{
Economic Impact from the Existence of Universiti Tenaga Nasional (UNITEN) in Muadzam Shah Town, Pahang, Malaysia: An Input-Output Approach
}

\author{
Zulkifli Abdullah1*, Noraini Ismail2, Suzaida Bakar3 \\ 1,2,3 Department of Finance and Economics, College of Business Management and Accounting, Sultan Haji Ahmad Shah Campus, Pa- \\ hang, Malaysia
}

\begin{abstract}
Muadzam Shah is a small town in Rompin District, Pahang, Malaysia, established in 1979 by the South-East Pahang Development Authority (DARA). It is a quiet and tranquil agricultural based economy area and is a brainchild of Malaysia's second Prime Minister Tun Abdul Razak. The advent of University Tenaga Nasional in 2001 had changed the landscape of the local economy. Following the concept of "Town University", UNITEN has successfully contributed to amplify the local economy into a greater level, from the oil-palm industry area to a multi-sectoral economy such as retailing sector, food industries, hospitality as well as healthcare industry. Besides, UNITEN also serves as a medium of community and intellectual development between the academia and the society. By adopting Leontief inputoutput approach, this paper is designed to determine the economic multiplier effect that students and faculty staffs have on the local economy and community in Muadzam Shah.
\end{abstract}

Keywords: Muadzam Shah, University Tenaga Nasional, Economic Impact, Input-Output, MultiplierEffect

\section{Introduction}

Every injection in economy will likely to have a multiplier effect. This is because an injection of income leads to more spending, which creates more incomes and spirally create new spending, savings and other related businesses. The size of the multiplier depends upon the amount of the injections and household's marginal decisions to spend, known as Marginal Propensity to Consume (MPC), or to save, named as Marginal Propensity to Save (MPS). It is important to note that when income is spent, the spending becomes someone else's income. Marginal propensities show the proportion of income allocated to particular activities, such as a spending by staffs and students of Universiti Tenaga Nasional (UNITEN) in Muadzam Shah.

The nature of many Higher Education Institutions (HEI's) is such that they draw resources from the regional and or national economy while their physical operations are locally based. Taking these conditions into consideration, a college or university may conduct an economic impact study to examine its financial costs and contributions to its surrounding communities.

UNITEN Muadzam Shah Campus was officially opened on May 4, 2001 by the fourth Prime Minister of Malaysia, Tun Dr. Mahathir Mohamad. Following the concept of "Town University", UNITEN Sultan Haji Ahmad Shah Campus has the potential to be a catalyst towards the advancement of intellectual resources in accordance with the economic development of Bandar Muadzam Shah. It also serves as a medium of community, economic and intellectual development for Muadzam Shah and its surrounding areas. In 2001, there were only 252 students enrolled at UNITEN Muadzam Shah as its first ever intake and in 2016, there were 3,712 students studying in various programs such as Accounting, Finance, Entrepreneur Development, Marketing, Human Resources and International Business Studies.
Considering to the latest development of number of students' enrollments in Muadzam Shah, this study is motivated (1) To determine the economic impact from the existence of UNITEN in Muadzam Shah, (2) To identify the economic multiplier using Leontief input-output approach and (3) To provide a trend analysis on economic development in Muadzam Shah. This study is expected to produce an economic multiplier and economic impact from the existence of UNITEN in Muadzam Shah as well as providing a trend of socio-

economic development in the area. The study is conducted to furnish key stakeholders of the universities including the Tenaga Nasional Berhad (TNB), state government and local business of the nature and dimensions economic impact of the existence UNITEN now and in the future.

\section{Literature review}

Economic impact studies are useful tools many higher education institutions utilize to examine their effect within their local and/or regional economies. While the economic impacts of a college or university are varied and far-reaching, they can be considered as either effects on knowledge creation, research and development, or as effects of the direct and indirect expenditures flowing into the surrounding economy (Stokes \& Coomes, 1998). Institutional studies have been conducted to illuminate the former impact and thus describe the economic effects of the transmission and discovery of knowledge and ideas, conducting pure and applied research, and the development of new technologies and industries (Ohme, 2003). While these studies estimate the effect on the labor market in both the short-term and long-term, other studies investigate the latter effects of economic impact created by the institution's pur- 
chasing of goods and services from within its local economy (Parsons \& Griffiths, 2003).

According to Deloitte Access Economics Report (2014), based on a findings on two major Australian universities which are the Australian National University (ANU) and the University of Canberra (UC) shown as a progressive institutions in Australian society, which contributing to many aspects of economic development and social cohesion. Universities today do much more than provide education services to students and foster academic research, increasingly engaging with government, business and the local community as well as fostering international links. As a result of these activities, universities: in and of themselves are significant employers of research, teaching and administrative staff. In addition, businesses catering to staff and students are also employers; support innovation and economic development beyond the campus; encourage better employment outcomes for students and the regions they reside in; and promote better socio-economic outcomes for society more broadly. There are well established relationships between education and wellbeing, for example, in terms of health, social cohesion, crime and justice outcomes.

From different findings on the multiplier effects, Christiano, Eichenbaum and Rebelo (2009) argued that the government-spending multiplier can be much larger than one when the zero lower bound on the nominal interest rate binds. The larger is the fraction of government spending that occurs while the nominal interest rate is zero, the larger is the value of the multiplier. The model of multiplier effect is substantially larger than one when the zero bound binds.

Frechtling (1999) in a research on tourism multipliers indicated the total increase in output, labor earnings, and employment through inter-industry linkages in a region as a result of tourism expenditures. The research employed RIMS II regional inputoutput model to estimate the multiplier effects of visitor expenditures in Washington, D.C. Both normal multipliers and ratio multipliers were analyzed, and the latter is found to be a more reliable indicator of total impact on earnings and employment in the city. A comparison of the multipliers for 37 industry sectors and the tourism multiplier in the city finds that the latter ranks relatively high for earnings and employment, but low for output.

Bergstrom, Cordell, Ashley and Watson (1990) attempted to examine the local economic effects of spending on outdoor recreation in selected rural areas. Recreational expenditures were collected as part of the Public Area Recreation Visitors Study (PARVS). Economic impacts of these expenditures were estimated using regional input-output models developed from the USDA Forest Service input-output model and data base system (IMPLAN). Results indicated that recreational spending contributed substantially to gross output, income, employment, and value added in the studied rural areas. These results suggest that outdoor recreation may be a viable rural economic development strategy. Chhabra, Sills and Cubbage (2003) endeavored to estimates the economic impacts of visitor expenditures at two Scottish festivals in rural North Carolina, using tourist survey data and an inputoutput model. While local restaurants and lodging and festival vendors and sponsors benefit from substantial visitor expenditures, the multipliers are relatively small, and hence the total economic impact of the festivals represents only a small percentage of economic activity in the two regions considered. The study concluded that lodging expenditures have the greatest impact on the region with a multiple-day festival, while expenditures on food and beverage have the greatest impact on the region with a single-day festival. The magnitude of the economic impact depends on characteristics of both the festival (number of days) and the local economy (other attractions and linkages).

Wagner (1997) accessed a social accounting matrix to examine the economic effects of tourism in a Brazilian region. The study produced a systematic framework for synthesizing and displaying the data on a region's economy and estimating regional economic multipliers. It should be noted that most of the inputs, commodities, and capital used in the region were imported. Therefore, mon- ies tourists spent were used to pay for these imports and generate only a small economic impact to the country.

On a different note, input-output methodology has been widely used to measure the multiplier impact on tourism sector. Hosney (Harry) Zurub, Alexandru Ionescu, Valentina Daniela Constantin (2015) have measured the economic multiplier impact of tourism in European emerging markets. The study reveals that the majority of developed economies consider tourism a fundamental industry for their economic growth because it depends on other productive sectors making the infrastructure of a zone and cycling its economic wheel. The elimination of business complexity at both macro- and microeconomic level can help developing markets to reach a higher level of efficiency and eventually increase quality. The United States economic earnings of tourism industry is about $\$ 110$ billion annually.

Timothy S.Mescon, George S.Vozikis (1985) meanwhile studied the economic impact that cruise industry tourism has on Dade County using a regional input-output model developed by the Regional Science Research Institute. It has been concluded that the tourism industry had a total economic impact on Dade County of $\$ 546$ million in 1982. The total direct, indirect and induced number of jobs generated by the cruise industry and cruise passengers is 21,627. Wages totaling \$271 million were paid in 1982 in Dade County as a result of the total impact of the cruise industry. The model also revealed that cruise industry tourism contributed \$264 million to the county's Gross Regional Product in 1982. The study utilizes the Archer tourism multiplier methodology by adopting a price level adjusted twenty-nine sector input- output framework as the basis for calculating the tourist multipliers.

Douglas C. Frechtling, Endre Horváth (1999) employed RIMS II regional input-output model to estimate the multiplier effects of visitor expenditures in Washington, D.C. Both normal multipliers and ratio multipliers were analyzed, and the latter found to be a more reliable indicator of total impact on earnings and employment in the city. A comparison of the multipliers for 37 industry sectors and the tourism multiplier in the city finds that the latter ranks relatively high for earnings and employment, but low for output.

Daniel Shoag (2010) adopted an identification strategy to isolate exogenous and unexpected variation in state government spending. State governments manage large defined-benefit pension plans for which they bear the investment risk. Baseline analysis indicate that each dollar of spending raises in-state income by 2.12 , and that 35,000 of spending generates one additional job. These effects are not due to in-state investment bias, are concentrated in the non-traded sector, and are larger during times of labor force 'slack.'

Smith, V.; Wilde, P (1980) had investigated the multiplier impact of tourism in western Tasmania. The result has been shown to be greatly influenced by the structure of the local economy. In general, spending in relatively small, locally owned, labour intensive enterprises have most impact in the region, while larger, externally controlled establishments are usually less integrated within the local economy. In the field of accommodation, for example, smaller concerns are likely to be more dependent on local retailers and to spend their income and profits locally and so have a greater local multiplier effect than large motels. The degree of selfsufficiency of the entire local economy is also a major factor determining the size of the regional tourist multiplier. Thus the more general activity which can be encouraged to establish in the region, the greater will be the local impact of any increase in tourist numbers or spending. The extension of the range of retailing and service activities and the introduction of more local wholesaling seem the most likely areas of growth. Nevertheless, it is inevitable that the leakage from the regional economy of western Tasmania will be high, so that some of the multiplier effect will be passed on to the economies of other regions. Given this interdependence of regional economies within Tasmania it would seem reasonable that State funds should be used to meet some of the costs associated with tourism. 


\section{Methodology}

In May 2017, economic impact questionnaires were distributed to students and staffs at UNITEN Muadzam Shah Campus. A follow-up mailing and focused-group discussion was conducted in July. The student questionnaire was administered to a sample of approximately $30 \%$ of 3,712 undergraduate students at the University. The students were randomly selected to ensure a representative sample by gender, ethnicity and class level. The student response rate was approximately $17.6 \%$. The final student data set was weighted during analysis to correctly represent the overall percentages of students by gender, time status, class level and residence status. The weighted data thus provide findings from the sample of students to reflect the actual student population. The students were primarily requested to share their spending behavior in the questionnaires, which then broken down to spending for foods, clothes, petrol and gas, telecommunication phone bills, entertainment and recreation, house rentals and investments.

On the same note, the staff questionnaires were administered to a sample of approximately $30 \%$ of 249 staff members at UNITEN Muadzam Shah Campus. The data set originally contained 75 surveys and approximately $67 \%$ of the staffs have responded. Similar to students' data set, the final data set was weighted during analysis to give correct representation to overall percentages of staff members by departments. The weighted data thus provide findings from the sample of staff to represent the campus departments and staff population. All of the data collected have been summarized to arrive the total spending by the university staffs and students. The total spending from each category has subsequently been matched with relevant sectors in input-output table provided by Department of Statistics Malaysia.

An input-output is a quantitative economic technique which developed by Wassily Leontief, a Nobel Prize winner in economics during rapid Soviet Union's industrialization. The idea of Leontief Input Output Model is based on a matrix $\mathrm{C}$, which is called Consumption Matrix. The (i,j) entry of $\mathrm{C}$, (that is $\mathrm{Ci}, \mathrm{j}$ ) is the (monetary value of) output from industry $\mathrm{i}$ which is needed to produce one unit (of monetary value) of output of industry $j$. In other words if industry $\mathrm{j}$ wants to produce one unit of its own product, it needs to consume Cij units of the output of the industry i. Suppose that we have $\mathrm{n}$ industries and each produce xi units. The production vector $\mathrm{p}$ is defined as:

$$
p=\left|\begin{array}{l}
X_{1} \\
X_{2} \\
X_{n}
\end{array}\right|
$$

The consumption by industries will be $\mathrm{Cp}$. And, $\mathrm{p}-\mathrm{C}=(\mathrm{I}-\mathrm{C}) \mathrm{p}$ is the amount available for external use. And for the demand, $d$, from outside of the system as:

$$
d=\left|\begin{array}{l}
d_{1} \\
d_{2} \\
d_{n}
\end{array}\right|
$$

Where, di shows the demand for the output of the industry i. A for this study, the students and staffs spending act as input to the economy in Muadzam Shah and the output will be the business community from various sectors.

\section{Results and analysis}

\subsection{Student economic impact}

The advent of UNITEN in Muadzam Shah town had significantly contributed to the local economic growth. Based on our survey, the spending mean of the students in 2016 stood at RM500 a month. With a total number of 3,712 students, this monthly spending translates into RM1.86 million per month or equivalent to
RM19.02 million per year, calculated based on students' academic calendar 10.25 months a year.

The overall students' spending has given an economic multiplier of $1.495 \mathrm{x}$, translating into an every one ringgit of students' spending has directly and indirectly magnified the local economy by RM1.495. By sector, wholesale and retail, electricity and gas and telecommunication are the most benefited sectors, accounting $67 \%$ of the total students' spending. The wholesale and retail sector is mainly represented by the spending on food and beverages while electricity and gas and telecommunication sub-sector constitute of electricity consumption and fuel expenses and phone bills respectively. Other beneficiaries include entertainment, financial institution, rental and leasing (house rentals) and healthcare sector.

Table 1: Direct impact of students' spending by sector

\begin{tabular}{|l|l|l|}
\hline Sector & Direct Impact & Share \\
\hline Wholesale and retail trade & RM $7,099,609$ & $37.00 \%$ \\
\hline Electricity and gas & RM $2,816,192$ & $15.00 \%$ \\
\hline Telecommunication & RM $2,794,514$ & $15.00 \%$ \\
\hline Entertainment & RM $2,294,419$ & $12.00 \%$ \\
\hline Financial institution & RM $1,762,846$ & $9.00 \%$ \\
\hline Rental and leasing & RM $1,602,791$ & $8.00 \%$ \\
\hline Healthcare & RM 646,835 & $3.00 \%$ \\
\hline Others & RM $\quad 6,367$ & $0.03 \%$ \\
\hline Total & RM19,023,573 & $100.00 \%$ \\
\hline
\end{tabular}

In the past sixteen years, at discount factor of 3\%, the total UNITEN students' spending in Muadzam Shah establishment had reached to RM149.5 million, growing at Compound Annual Growth Rate (CAGR) of $23.47 \%$ per year.

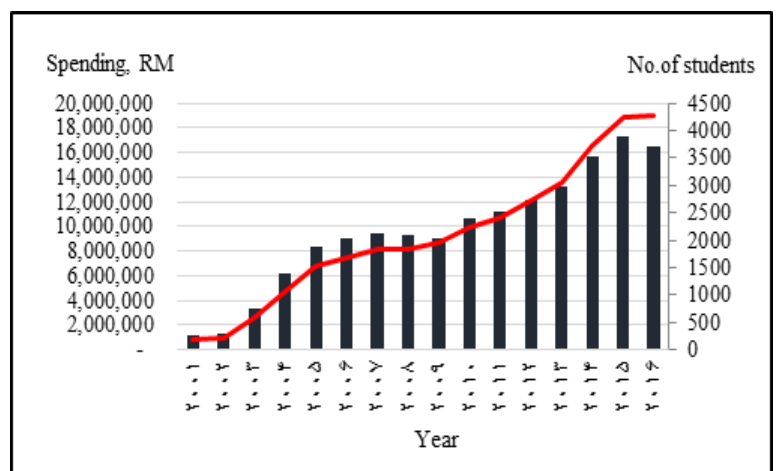

Chart 1: UNITEN Muadzam Shah Campus students' spending (annual average 2001-2016)

On the same note, the total students' spending had indirectly boosted the local economy by $0.495 x$ or RM9.42 million which giving benefits to another 122 sectors. The total value of the impact reached RM28.4 million in 2016. The top 10 sectors account $14 \%$ of the total 122 sectors. In total, the students' spending has boosted the local economy both direct and indirect by RM28.4 million in 2016

Table 2: Top 10 indirect impact of students' spending by sector

\begin{tabular}{|l|cc|l|}
\hline Sector & Indirect Impact & Share \\
\hline Petroleum refinery & RM 204,331 & $2.20 \%$ \\
\hline Oils and fats & RM 202,108 & $2.10 \%$ \\
\hline Professional & RM 159,795 & $1.70 \%$ \\
\hline Real estate & RM 132,286 & $1.40 \%$ \\
\hline Accommodation & RM 114,628 & $1.20 \%$ \\
\hline Crude oil and natural gas & RM 107,544 & $1.10 \%$ \\
\hline Ownership of dwellings & RM 104,020 & $1.10 \%$ \\
\hline Health & RM 103,219 & $1.10 \%$ \\
\hline ICT and computer services & RM 94,996 & $1.00 \%$ \\
\hline Oil palm & RM 91,909 & $1.00 \%$ \\
\hline Other 122 sectors & RM 8,101,833 & $86.00 \%$ \\
\hline Total & RM 9,416,669 & $100.00 \%$ \\
\hline
\end{tabular}

4.2. Staff Economic Impact 
The mean spending of staffs in Muadzam Shah for 2016 was RM2,294 a month. With 249 staffs, a sum of RM571,206 per month or RM6.85 million has been pumped into the local economy. The overall staff's spending give multiplier of $1.468 \mathrm{x}$. This implies that every ringgit of spending is associated to directly and indirectly magnify the economy by RM1.468.

Table 3: Direct impact of staffs' spending by sector

\begin{tabular}{|l|c|l|}
\hline & Direct Impact & Share \\
\hline Real estate & RM 1,516,349 & $22.00 \%$ \\
\hline Motor vehicles & RM 916,165 & $13.00 \%$ \\
\hline Vholesale and retail trade & RM 903,805 & $13.00 \%$ \\
\hline Financial institution & RM 874,639 & $13.00 \%$ \\
\hline Motorcycles & RM 562,268 & $8.00 \%$ \\
\hline Electricity and gas & RM 551,795 & $8.00 \%$ \\
\hline Banks & RM 499,605 & $7.00 \%$ \\
\hline Insurance & RM 320,180 & $5.00 \%$ \\
\hline Education & RM 218,660 & $3.00 \%$ \\
\hline inema, video and television activity & RM 203,041 & $3.00 \%$ \\
\hline Others & RM 287,966 & $4.00 \%$ \\
\hline Total & RM 6,854,472 & $100.00 \%$ \\
\hline
\end{tabular}

By sector, real estate, motor vehicle and wholesale and retail trade are the most benefited sector accounting $48 \%$ of the total economic impact in 2016. These three sectors received RM7.98 million for the staffs' spending. At discount factor of 3\%, the total UNITEN staffs' spend in Muadzam Shah since its establishment had reached to RM56.8 million, growing at CAGR $11.74 \%$ per year.

Table 4: Indirect impact of staffs' spending by sector

\begin{tabular}{|l|r|l|}
\hline Sector & Indirect Impact & Share \\
\hline Rental and leasing & RM 487,137 & $15.20 \%$ \\
\hline Telecommunications & RM 128,731 & $4.00 \%$ \\
\hline Petroleum refinery & RM 101,409 & $3.20 \%$ \\
\hline Professional services & RM 74,029 & $2.30 \%$ \\
\hline Private non-profit institution & RM 70,179 & $2.20 \%$ \\
\hline Crude oil and natural gas & RM 53,335 & $1.70 \%$ \\
\hline Restaurants & RM 52,925 & $1.60 \%$ \\
\hline Oils and fats & RM 51,646 & $1.60 \%$ \\
\hline ICT and computer services & RM 32,457 & $1.00 \%$ \\
\hline Health & RM 24,209 & $0.80 \%$ \\
\hline Other 110 sectors & RM 2,134,334 & $66.50 \%$ \\
\hline Total & RM 3,210,393 & $100.00 \%$ \\
\hline
\end{tabular}

$\left.\begin{array}{|l}\text { Spending, RM } \\ 8,000,000 \\ 7,000,000 \\ 6,000,000 \\ 5,000,000 \\ 4,000,000 \\ 3,000,000 \\ 2,000,000\end{array}\right]$

Chart 2: UNITEN Muadzam Shah Campus staffs' spending for annual average from year 2001 until 2016

Indirectly in 2016, the staffs' spending has helped to boost the local economy by 0.468 or RM3.2 million in which also benefiting 110 sectors. The total value of the impact had reached RM10.06 million with the top 10 sectors account $33.5 \%$.

\section{Conclusion}

All in all, the student and staff expenditures have magnified the local economy by $1.495 \mathrm{x}$ and $1.468 \mathrm{x}$ respectively. In the last sixteen years, the expenditure had directly contributed RM206.16 million and indirectly helped to enlarge the economy by another
RM100.5 million to give a total impact of RM 306.68 million. Of this, RM the students and staffs contributed $73 \%$ and $23 \%$ respectively. UNITEN Muadzam Shah will remain as a driving force towards transforming the local economy over the coming years.

\section{Acknowledgments}

This project is financially supported by UNITEN Internal Research Grant (UNIIG) (J510050662) of Universiti Tenaga Nasional (UNITEN).

\section{References and Notes}

[1] Bergstrom, J. C., Cordell, H. K., Ashley, G. A., and Watson, A. E., Economic Development Quarterly. 4(1), 29-39 (1990).

[2] Chhabra, D., Sills, E., and Cubbage, F. W., Journal of Travel Research. 41(4), 421-427 (2003).

[3] Christiano, L., Eichenbaum, M., and Rebelo, S., Journal of Political Economy. 119(1), 78-121 (2011)

[4] Daniel Shoag, Harvard University, Evidence on the Multiplier from State Pension Plan Returns. (2010)

[5] Deloitte Access Economics, Higher Learning: Economic and Social Impact of the Major Universities in the Australian Capital Territory.

[6] Douglas C. Frechtling, Endre Horváth, Estimating the Multiplier Effects of Tourism Expenditures on a Local Economy through a Regional Input-Output Model, Volume: 37 issue: 4, page(s): 324332 (1999)

[7] Frechtling, D. C., and Horvath, E., Journal of Travel Research. 37(4), 324-332 (1999).

[8] Hosney (Harry) Zurub, Alexandru Ionescu, Valentina Daniela Constantin, Measuring the Economic Impact of Tourism in European Emerging Markets, Volume 32, 2015, Pages 95-102 (2015)

[9] Ministry of Higher Education. Recent Trends and Future Developments.

[10] Ohme, A., University of Delaware. (2003).

[11] Parsons, R., and Griffiths, A., Association for Institutional Research (AIR), Professional File. (87), 24 (2003).

[12] Smith, V.; Wilde, P., Tasmanian Education Department, Tasmania, Australia. pp.165-172 ref.fig., tab., 23 (1980)

[13] Stokes, K., and Coomes, P., AIR Professional File. 67(6) (1998).

[14] Timothy S.Mescon, George S.Vozikis, The economic impact of tourism at the port of Miami, Volume 12, Issue 4, 1985, Pages 515528 (1985)

[15] Wagner, J. E., Annals of Tourism Research. 24(3), 592-608 (1997). 